\title{
Thoughts on the Integration of Information Technology and Learning Style in the Chemistry Curriculum of Middle Schools
}

\author{
Dongfang HUANG, Linhai JING, and Guangyu BAO \\ Beijing Academy of Educational Sciences, Beijing, CHINA
}

\author{
bjshuzixuexiao@126.com, JLH101@263.net, baogyu@163.com
}

\begin{abstract}
Chemistry is taught in Grade 9. It is a compulsory course in Grade 10 and an elective course for science students in Grade 11 and 12. As a cognitive tool, information technology has a great value for chemistry education. First, it has promoted a change in chemistry education philosophy, the impact of which is mainly manifested in the following aspects. Second, it has realized the integration and optimization of chemical learning resources. Third, it has promoted the change of chemical learning style: from acceptation to exploration.
\end{abstract}

Keywords: information technology, integration, learning style, chemistry curriculum, middle schools, student-centered learning, resources

\section{Introduction}

The integration of information technology and learning style is the core of applying information technology in education. The integration of information technology and learning refers to the application of information technology with computer multimedia technology and computer network technology at the core in teaching, changing the way students study and communicate and realize a true sense of digital learning. What is the significance of information technology in changing chemistry learning style? This paper attempts to start from the perspective of chemistry teaching to understand the significance of integrating information technology with learning style, analyze its development situation and put forward a number of issues for further study.

\section{Integration}

Information technology is one of educational technology which develops from visual movement (1918-1928) and audio-visual education campaign (1918-1942) into an educational technology

Material published as part of this publication, either on-line or in print, is copyrighted by the Informing Science Institute. Permission to make digital or paper copy of part or all of these works for personal or classroom use is granted without fee provided that the copies are not made or distributed for profit or commercial advantage AND that copies 1) bear this notice in full and 2) give the full citation on the first page. It is permissible to abstract these works so long as credit is given. To copy in all other cases or to republish or to post on a server or to redistribute to lists requires specific permission and payment of a fee. Contact Publisher@InformingScience.org to request redistribution permission. focusing on audio-visual media (after World War II or the 1960s). Meanwhile, the application of computer technology education forms computer-assisted instruction (beginning from the 1950s), CAI for short. In the late twentieth, network technology has developed rapidly and become more popular, especially the connection of the Internet and campus network, providing a broader out- 
look and more abundant resources for school education and creating a web-based teaching form (Web-Based Instruction, referred to as WBI)( LI \& WANG, 2000).

The development process of applying computer technology into chemical learning is in line with the above process. The basic process is shown in Figure 1.

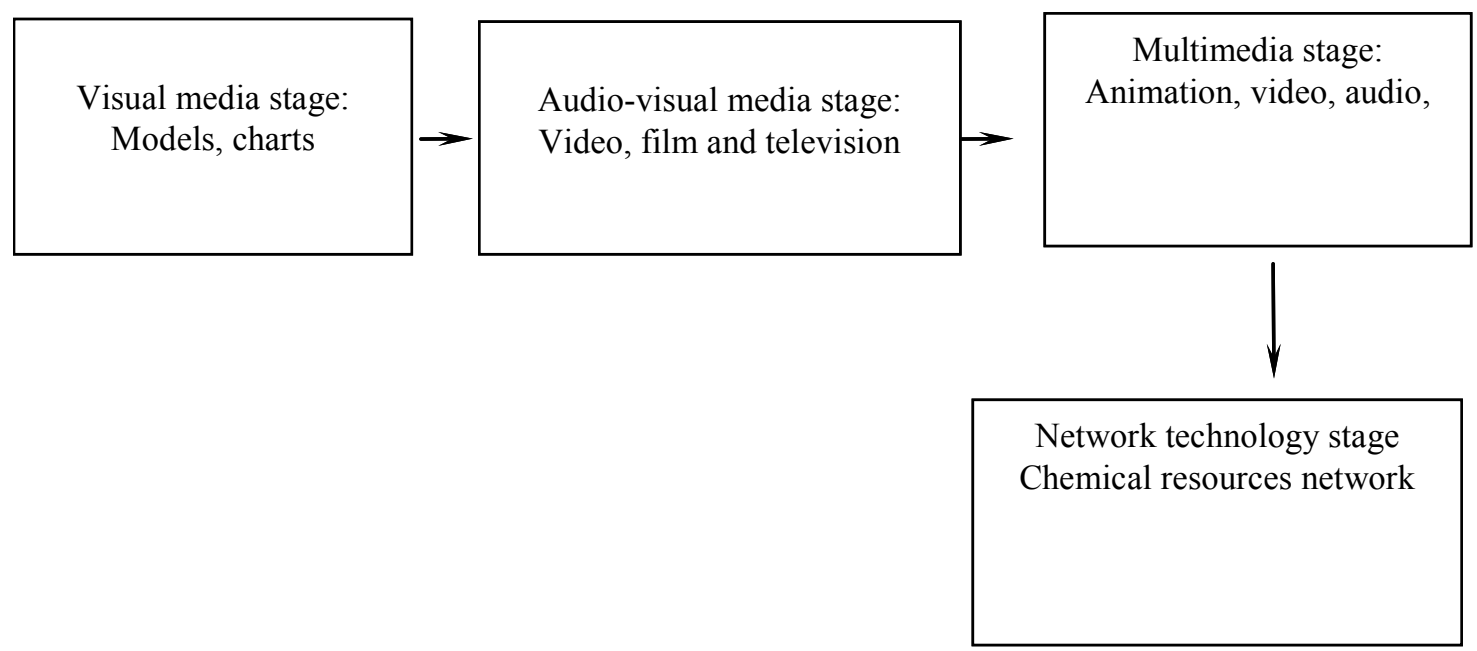

Figure 1. Basic Process for Applying Computer Technology

These stages develop with the improvement of educational technology. In the late stage, it is the comprehensive application of various media and various methods, with computer multimedia and network technology as its core. The following chart shows that according to the extent of the application, "integration" can be divided into different levels.

Ideal level: integration of information technology and subject curriculum

Regard information technology as important and essential means of teaching and learning.

Regard the improvement of students' ability to apply information technology into the exploration of subject problems as the main purpose.

Higher level: computer-aided students learning

Take the main form of students' operation of computer.

Regard helping students acquire subject knowledge as the main purpose.

Basic level; computer-aided teacher teaching

Take the main form of teachers' operation of computer.

Regard the students' comprehension of subject knowledge as the main purpose.

Subject knowledge to help students understand the main purpose 
According to the explanation of Educational Technology Standards of American Students, integration of information technology and curriculums refers to the integration of technology taking the form of a tool and curriculums to promote the learning of certain knowledge area or multidisciplinary field. Information technology enables students to study in an unprecedented way. Only when the students are able to choose tools to help them timely acquire, analyze, and integrate information and skillfully express it will the integration of technology and curriculum be effective. Technology should, like other available teaching aids, become an integral part of the classroom. Thus, as Professor Cleburne D. Maddux majoring in Educational Technology in American University of Nevada pointed out, "It is clearly not enough if educators only consider how to introduce interactive network into the classroom, which cannot produce any educational effect. Only when they truly connect interactive network with schools' teaching goals and students' learning process in a close way will it play a huge educational value" (Maddux, 2012).

\section{Significance of Integrating Information Technology with Chemistry Learning Style}

What is the significance of information technology in changing chemistry learning style? For example, a student in Grade 11 got information from the Internet: the research winning 2005 Nobel Prize in Chemistry revealed the mechanism and process of olefin metathesis. At this point, this student was learning olefins. He asked his chemistry teacher two questions on this information: firstly, the olefins we learned could make addition reaction and substitution reaction. But metathesis reaction was not mentioned in the book. What's more, the types of organic reaction did not include metathesis reaction; secondly, it was said on the Internet that 2005 Nobel Prize in Chemistry realized "the return of chemistry." How to understand it?

This example illustrates that information technology has created a vivid and trans-time-and-space digital learning environment for students. It is quietly affecting the way students study. Our teachers must not turn a blind eye to it. Instead, they should use a clear mind to face the arrival of this change and consciously and actively play a positive role of information technology to achieve teaching objectives.

\section{Produce a profound impact on chemistry learning concept}

For science education, the modern educational technology mainly embodies the expansion and externalization of human cognitive potential. Therefore, some education experts call modern educational technology "cognitive technology" which can help students go beyond the limits of thinking, learning and solving problems. Information technology, as a cognitive tool, has promoted the changes of chemistry education ideas. Its impact is mainly manifested in the following aspects. Firstly, emphasize student-centered chemical education. Secondly, provide chances for students to get experience. Thirdly, enhance students' thinking and innovation in learning activities. Fourthly, take a fresh look at the authority of knowledge.

\section{Realize the integration and optimization of chemistry learning resources}

Chemistry is the core science in the 21 st century. It is the foundation of research in medicine, materials, energy, environmental protection, and other disciplines and is increasingly connected with human social activities. The traditional chemistry curriculum resources are relatively closed and old, lack links with students' practical life and social actual production, and lack links with the chemical history and modern high-tech development. This is closely related with the means of course presentation. Information technology includes information networks, multimedia teaching systems, and various design tools, which greatly enriches the learning resources. Open course 
Integration of Information Technology and Learning Style

construction concept has a fundamental impact on the modes of presenting chemistry teaching content, mainly manifested in the following aspects.

Firstly, hypertext technology makes a breakthrough in the logical structure of chemistry with traditional teaching content. Secondly, Internet technology has greatly enriched the information resources of studying chemistry. Thirdly, multimedia technology optimizes the modes of presenting chemical knowledge.

\section{Promote the change of chemical learning style: From acceptation to exploration}

Traditional classroom teaching process and structure cannot meet the needs of cultivating innovative talents. The basic idea of modern science education is to advocate "learning by doing" among students. The reform of chemistry teaching in middle school is also trying to let students become the subject of scientific study. Information technology integration introduces information technology into chemistry teaching process comprehensively, making it an important tool and means for student learning, teaching and teacher-student interaction. It will become a "catalyst" of reform in chemistry teaching.

Firstly, the learning style of students is changed from acceptation to exploration. Secondly, the teaching method of teachers is changed from teaching to assistance. Thirdly, the teacherstudent/student-student interaction is diversified and individualized.

\section{Analysis of the Situation of Students' Use of Information Technology for Chemical Learning}

The Chemistry Teaching and Research Section of Teaching Research Centre of Fundamental Education, Beijing Academy of Educational Sciences has made several surveys on the applications of information technology in chemistry teaching of middle school from 1998 to the present, which involves the issue of students using information technology for chemical learning. Related research findings are mainly as follows (The following unpublished surveys were conducted by Ma \& Huang, 1998; Huang, 2001, 2013).

\section{Survey of 1998 (Ma \& Huang, 1998)}

Firstly, students' familiarity with computers.

Secondly, students' attitude towards the application of computer in chemistry teaching

Thirdly, students' understanding of computer-aided chemistry teaching

Fourthly, understanding of forms of information technology application from the perspective of students

Fifthly, students' views on courseware of chemical information technology

Sixthly, students' views on the learning materials of chemical information technology

\section{Survey of 2001 (Huang, 2001)}

For a more comprehensive and timely understanding of the actual situation of applying computer technology in chemistry teaching of Beijing middle schools to conduct relevant research and practice further, the Chemistry Teaching and Research Division conducted a questionnaire for 400 chemistry teachers of eight districts in Beijing in April, 2004 and held a forum for the city's key teachers. The survey and visit results about students' application of information technology in their study are as follows. 
Firstly, the application of computers in classroom is mainly presented by teachers, and the students watch the big screen.

Secondly, some teachers do not know the situation of students' application of computers in chemistry learning. Students have time to use computers for chemical learning. But, they mainly use computers for online chatting or playing video games after school.

Thirdly, teachers have not paid enough attention on how to guide students to use information technology for changing leaning style.

\section{Survey of 2013 (Huang, 2013)}

After more than ten years of curriculum reform and practice, information technology is developing rapidly and has been fully integrated into all aspects of life and education. In the implementation of chemistry curriculum of Beijing middle school, teachers use information technology in almost every class. Information technology has become one of the key indicators to measure the basic teaching skills of teachers. The following is the part of questionnaire results of 2013 Beijing middle school teachers' basic teaching skills, more than 1,400 junior high school chemistry teachers under the age of 50 in Beijing are involved in this research.

The findings of relevant questions indicate that teachers attach great importance to enhance their IT capabilities. $96.95 \%$ of teachers think that mastering information technology in modern education is more important or important.

Classroom observation and research results in recent years show that the use of PPT is still the main form, main content of which is the teachers' explanation, demonstration, and assignment of tasks. Some teachers encourage students to use the Internet for consulting resources after school and use mind mapping software to complete their homework, etc., but they are still in a small number.

\section{Conclusions}

Firstly, after several years of subject research and promotion around the city, the time, frequency and quality of using information technology by vast chemistry teachers have significantly improved. This gives more students more opportunities to learn chemical knowledge through information technology and achieves a better effect.

Secondly, a number of good research lessons have been produced, which highlights the main role of students and guides students to use information technology for chemical study. But the quantity and quality of these lessons are to be improved, especially the improvement of students' use of information technology in regular lessons and daily teaching, making students become masters of information technology applications.

Thirdly, compared with school learning process, the opportunities for students' use of information technology to carry out chemical learning are few, probably due to many factors. For example, today it is still dominated by the learning style focusing on traditional books, pens, and paper, to which teachers and students are comparatively accustomed; there are less effective integrated learning resources. Though students are in an ocean of information, it takes them a lot of time to retrieve and sort information, and they are easy to be interfered and confused by other irrelevant information. Teachers and families do not give enough guidance and supervision for students to use information technology in study. Many students like to use computers to play games or chat online rather than learn subject knowledge.

The significance of integrating information technology and learning styles is analyzed in above parts and the research situation of the students' application of information technology in learning 
Integration of Information Technology and Learning Style

chemistry is also introduced. It is clear that there is a big gap between reality and ideality. A lot of problems need to be both argued in theory and explored in practice.

(I) Build a real digital learning environment convenient for students to use information technology

(II) Use information technology properly based on the actual needs of students' learning

(III) Build a sustainable chemical learning resources network

\section{References}

Huang, D. (2001). The computer technology application survey of the chemistry course teaching and learning in Beijing Middle Schools (unpublished).

Huang D. (2013). The investigation report of chemistry course teachers' basic skills in Beijing Junior High School (unpublished).

Li, B., \& Wang J. (2000). The construction and thinking of network teaching mode. Curriculum, Textbook and Pedagogics, 10, 41-45.

Ma, S., \& Huang, D. (1998). The investigation report of computer aided chemistry course teaching and learning status in Beijing Middle Schools (unpublished).

Maddux, C. D. (2012). Distance education: Issues and concerns. Haworth Press Inc.

\section{Additional Source Material}

Wang, L. (2011). Review of the ten years' implementation of chemistry curriculum standard for compulsory education. Fundamental Education Curriculum, 2.

$\mathrm{Wu}, \mathrm{X} .$, \& $\mathrm{Du}, \mathrm{Z}$. (2011). Investigation and analysis on the implementation level of chemistry new curriculum. Chinese Journal of Chemical Education, 7.

Xin W., \& Zhou, S. (2009). Scientific inquiry the connotation of ontology in chemistry teaching and learning. Modern Primary and Secondary Education, 11.

Zheng, C. (2005). The chemistry curriculum and pedagogy. Northeast Normal University Press, 19-26.

Zhong, F. (2009). Discussion the connotation of 3-D objection of high-school chemistry course. Academy of Education, 12.

\section{Biographies}

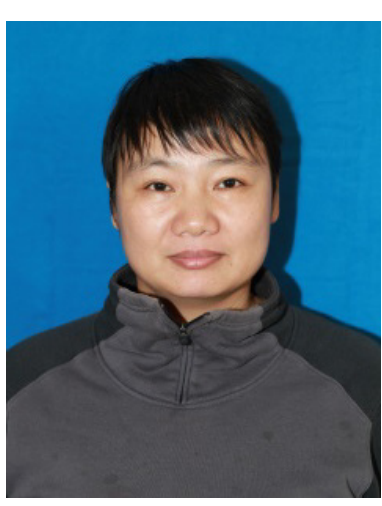

Prof. HUANG Dongfang finished the Master Degree of Chemistry Education and worked as a high-school teacher for 15 years. She is the senior teacher and her work and research field is Chemistry Education and IT implements in Chemistry teaching, learning and research. 




Prof. JING Linhai finished the Bachelor Degree of Biology and worked as a high-school teacher for 20 years. He is the senior teacher and Head of the Biology Teaching and Research Section, and very experienced in IT implements in Biology teaching, learning and research.

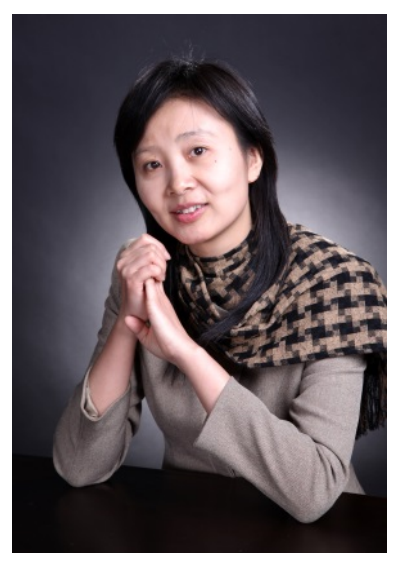

Ms. BAO Guangyu worked as a high-school teacher for 8 year, finished her Master of TESOL at University of Melbourne, and worked as Associate Operation Director at MBA Program Office at Peking University. Currently she works at Beijing Digital School Management Office of Teaching Research Center of Fundamental Education, Beijing Academy of Educational Sciences. 